\title{
Foreign Aid Shocks as a Cause of Violent Armed Conflict
}

\author{
Richard A. Nielsen Harvard University \\ Michael G. Findley Brigham Young University \\ Zachary S. Davis Brigham Young University \\ Tara Candland Brigham Young University \\ Daniel L. Nielson Brigham Young University
}

\begin{abstract}
In this study we resolve part of the confusion over how foreign aid affects armed conflict. We argue that aid shocks-severe decreases in aid revenues - inadvertently shift the domestic balance of power and potentially induce violence. During aid shocks, potential rebels gain bargaining strength vis-à-vis the government. To appease the rebels, the government must promise future resource transfers, but the government has no incentive to continue its promised transfers if the aid shock proves to be temporary. With the government unable to credibly commit to future resource transfers, violence breaks out. Using AidData's comprehensive dataset of bilateral and multilateral aid from 1981 to 2005, we evaluate the effects of foreign aid on violent armed conflict. In addition to rare-event logit analysis, we employ matching methods to account for the possibility that aid donors anticipate conflict. The results show that negative aid shocks significantly increase the probability of armed conflict onset.
\end{abstract}

I $\mathrm{n}$ the spring of 1990, Tuareg fighters in the North African Sahel launched a rebellion against the government of Mali. Although there were many underlying causes, foreign aid played a proximate role in the outbreak of violence. Desertification and severe droughts in the 1970s and 1980s impoverished Mali, especially the livestock-reliant Tuareg. During this period, Mali became heavily dependent on foreign aid; for many years Mali received more than $30 \%$ of its budget from international assistance, which at times was the largest source of government revenue. Flush with international aid, the government successfully managed a 1984 drought that threatened the Tuareg (Imperato 1989). The tenuous peace unraveled in 1989, however, when aid flows to Mali were drastically reduced, substantially weakening the government and preventing it from providing the same level of assistance to Tuareg communities then or into the future. In the following year, the Tuareg initiated their rebellion against the Malian government.

Richard Nielsen can be contacted through the Department of Government, Harvard University, 1737 Cambridge St., Cambridge, MA 02138 (nielsen.rich@gmail.com). Michael Findley (mikefindley@byu.edu), Zachary Davis (zacharysdavis@gmail.com), Tara Candland (taracandland@gmail.com), and Daniel Nielson (dan_nielson@byu.edu) can be contacted through the Department of Political Science, Brigham Young University, 745 Kimball Tower/PO Box 25545, Provo, UT 84602. Richard Nielsen contributed at all stages of the project and made the primary contribution to the empirics. Michael Findley contributed at all stages of the project and made the primary contribution to the theory. Zachary Davis contributed to theoretical development and research for the Mali case study. Tara Candland helped with data management and initial empirical analysis. Daniel Nielson contributed to the theoretical development and empirical strategy and managed the compilation of AidData and its financing. Davis and Nielsen conceived of the research topic, and Findley developed the research question. All five authors assisted in the final write-up.

We thank Robert Bates, Andrew Coe, David Davis, Paul Diehl, Matthew Kocher, Jim Kuklinski, Rebecca Nielsen, Robert Powell, Carie Steele, Beth Simmons, Michael Tierney, Dustin Tingley, Brian Urlacher, members of the Project Level Aid Database (PLAID) research team at Brigham Young University, participants at the 2007 annual meetings of the International Studies Association, and five anonymous reviewers at the AJPS for helpful comments and advice. Richard Nielsen is supported by a National Science Foundation Graduate Research Fellowship. AidData (formerly known as Project-Level Aid or PLAID) was supported by the Bill \& Melinda Gates Foundation; the William and Flora Hewlett Foundation; National Science Foundation grant SES-0454384; the College of William and Mary; and the College of Family, Home and Social Sciences, the Department of Political Science, and the David M. Kennedy Center for International Studies at Brigham Young University. Replication materials and a Supporting Information appendix are available at http://dvn.iq.harvard.edu/dvn/dv/rnielsen and http://politicalscience.byu.edu/faculty/mfindley/.

American Journal of Political Science, Vol. 55, No. 2, April 2011, Pp. 219-232 
Interested in explaining armed conflicts such as in Mali, researchers have advanced a number of explanations linking foreign aid ${ }^{1}$ to conflict. Some arguments suggest that aid intensifies existing ethnic cleavages, which can make conflict more likely (Esman and Herring 2003), or that foreign aid increases the payoffs to rebels of initiating a civil war by increasing the value of capturing the state (Grossman 1991, 1992). Other studies argue that aid decreases the risk of civil war by promoting economic growth and strengthening state capabilities (Collier and Hoeffler 2002). Yet these studies appear to assume that aid transfers are steady and predictable. As the Mali example illustrates, however, aid flows are often unstable and uncertain. By one estimate, foreign aid revenues are up to 40 times more volatile than government revenue (Bulir and Hamann 2006, 7). Scholars have mostly ignored the effects of aid instability on the onset of armed conflict, which may account for differing arguments and conclusions.

In this article, we apply rationalist explanations for war to contend that abrupt downturns in aid flows cause armed conflict. Aid shocks-severe decreases in aid revenues-disrupt the status quo by weakening the central government and emboldening potential rebels to challenge the government. Aid shocks cause inefficient conflict because of the commitment problem described by Powell: "large, rapid changes in the bargainers' relative power cause inefficiency" because the government cannot credibly commit to providing a flow of resources sufficient to make rebels indifferent between conflict and peace $(2004,232)$.

To be sure, both the weakened government and the newly empowered rebels would prefer to reach a peaceful bargain that avoids the inefficient destruction of resources via conflict. However, the sudden, deep, and temporary nature of aid shocks often precludes a peaceful agreement. To appease the rebels, the government needs to promise more resources than it can immediately deliver, but if aid flows return or are replaced by other income, the reempowered government has no incentive to continue its promised transfers. With the government unable to credibly commit to future resource transfers, the temporarily empowered rebels are motivated to attack.

It seems almost certain that this effect of aid shocks is largely inadvertent. Donors do not intend to provoke conflict. Instead, donors alter their aid portfolios to reflect current economic conditions (Dang, Knack, and Rogers 2010; Palmer, Wohlander, and Morgan 2002), in response

\footnotetext{
${ }^{1}$ We use the term aid as shorthand for development finance, which includes all grants and concessional loans from other governments and multilateral organizations intended for economic, social, and political development.
}

to changing trade or alliance relationships (Alesina and Dollar 2000), to further foreign policy objectives (Lai 2003; Lebovic 1988; McKinlay and Little 1977), or to buy votes when countries rotate onto the United Nations Security Council (Kuziemko and Werker 2006). Furthermore, aid decisions are usually uncoordinated: donors set largely independent policies that can cumulatively and stochastically result in dramatic aid decreases.

To assess the effects of aid shocks on armed conflict, we conduct a series of statistical tests using the most comprehensive source for development finance flows, AidData, which allows us to track bilateral and multilateral aid to 139 countries from 1980 to 2005. Initially, we use rare-events logistic regression with both random and fixed effects. Additionally, we address potential endogeneity by using matching techniques to explicitly model the precipitants of aid shocks, including the factors conditioning donors' perceptions of impending violence. We subject the results to many robustness checks, which together offer compelling evidence that aid shocks increase the probability of armed conflict.

Given that more than $\$ 160$ billion flows annually from rich to poor countries, the finding that aid shocks trigger violence has important policy implications. Unlike other shocks that also might provoke conflict through a commitment problem, aid shocks are manipulable and thus avoidable. In what follows, we outline the context for the research, develop the argument, and subject it to rigorous empirical analysis.

\section{Foreign Aid and Conflict}

Foreign aid, as we consider it, consists of transfers from one or multiple governments to another for the purposes of economic, social, and political development. ${ }^{2}$ Recipient need is one of the primary factors that donors consider when they give aid, but aid flows are influenced by many other concerns, such as donor economic conditions, the strategic importance of the recipient, and interstate rivalries such as those that dominated the Cold War (e.g., Alesina and Dollar 2000; Berthelemy 2006; Neumayer 2003b).

Addressing the specific effects of aid on conflict, two camps have developed. On the one hand, scholars argue

\footnotetext{
${ }^{2}$ We exclude military aid for the purposes of this study. It is possible that military aid has similar effects, but the data are not available from most donors, making this proposition difficult to test. However, when we employ U.S. military aid along with economic assistance, the hypothesized effect is even stronger (see the Supporting Information).
} 
that aid increases the spoils to be won from rebellion (Azam 1995; Grossman 1991). Although the government may use aid to deter rebellion, deterrence is not always successful, and rebels may decide to go to war to win control of the aid rather than settle for what the government offers. On the other hand, scholars argue that aid decreases the likelihood of civil war indirectly. Collier and Hoeffler (2002) argue that aid can potentially prevent civil war by spurring economic growth, by reducing government reliance on primary commodity exports (a potential source of rebel funding), and by increasing government military capacity, perhaps through aid fungibility (Collier and Hoeffler 2007; Feyzioglu, Swaroop, and Zhu 1998). Similarly, de Ree and Nillesen (2009) find that increased aid reduces civil war duration, an effect that they attribute to the government's ability to increase military spending and thus deter rebellion.

These studies largely assume that aid is both stable and certain. Although some countries do receive ongoing flows of aid from year to year, much aid is highly volatile (Bulir and Hamann 2006; Eifert and Gelb 2005). After commodity prices, aid revenues are the most significant source of external fluctuations, accounting for $25 \%$ of all exogenous shocks, ahead of natural disasters, humanitarian crises, fluctuations in the GDP of high-income countries, and variation in the international interest rate (Raddatz 2007). Strikingly, aid appropriation is up to 40 times more volatile than government revenue (Bulir and Hamann 2006, 7). ${ }^{3}$

Studies examining aid volatility are nearly unanimous in their belief that aid volatility carries with it severe negative consequences (for examples, see Agenor and Aizenman 2010; Bulir and Hamann 2003, 2006; Eifert and Gelb 2005; Ndaruhutse and Brannelly 2006). And as we argue here, variance in aid flows may cause conflict. Lensink and Morrissey (2000), for example, find that aid uncertainty significantly decreases economic growth, thereby decreasing the opportunity cost of going to war and potentially creating new grievances associated with poverty. More directly, Arcand and Chauvet (2001) present a model that suggests that variability in aid revenues increases the risk of civil war in two ways: by enlarging the potential payoff for rebellions and by varying the level of fungible resources governments can use for deterrence.

Average aid volatility over multiple years may indeed be an important cause of conflict; however, as we argue here, the effects of large, rapid drops in aid have effects

${ }^{3}$ Collier (1999) suggests that aid may not be as volatile as tax revenues, although this study is clearly in the minority and relies on much less data. on conflict that should be evaluated in their own right. Moreover, volatility cannot distinguish between the potentially different downstream effects of positive versus negative fluctuations. We therefore advance the discussion of aid fluctuations and conflict by introducing the concept of aid shocks.

\section{Aid Shocks, Bargaining Failure, and the Onset of Armed Conflict}

In most societies, peaceful arrangements divide finite resources among citizens and competing government and opposition factions (Azam 1995, 2001; Fearon and Laitin 1996). ${ }^{4}$ Governments may buy out potential rebels by committing a sufficient flow of resources to make them unwilling to seek more through fighting. Such buyouts might include (1) formal political power and resourcesharing agreements that constitute a legal accord between conflicting parties, (2) side-payments in the form of direct financial transfers, (3) indirect transfers via differential taxation or public goods provision, and (4) implicit understandings that if a particular region or ethnic group does not receive sufficient funds from government coffers, rebellion might result. In addition to these transfers (or in place of them), governments may also spend resources to deter potential rebels from fighting by raising the probability of a government victory in an armed conflict. Foreign aid contributes to government resources and, as such, forms a key basis of government side-payments or deterrence. Commonly, such status quo arrangements are thought to reflect the underlying distribution of power, raising the question of what consequences occur when the distribution of power shifts due to changes in foreign aid.

We argue that rapid changes in aid flows-aid shocks-can grow large enough to materially affect the balance of power between a government-the sovereign recipient of aid flows-and potential rebels, which we define as individuals or groups that might use violence to oppose the government. ${ }^{5}$ Potential rebels might still

\footnotetext{
${ }^{4}$ The peaceful equilibrium, regardless of its strength, is not necessarily "just"; it simply refers to an equilibrium characterized by a lack of violence, which may or may not be upset as time goes on.

${ }^{5}$ Our emphasis on aid shocks shares more in common with literature on other kinds of discrete shocks—-such as economic crises or environmental disasters - than with the volatility literature. Rodrik (1999), for example, argues that negative terms-of-trade shocks led to short-term reductions in growth rates and unemployment, which indirectly led to a higher probability of armed conflict. Scholars have also found that rapid environmental change or disaster
} 
be emerging, or they may already be extant social movements endowed with significant organizational capacity. Changes in aid can be either negative or positive: we refer to large positive changes as positive aid shocks and large negative changes simply as aid shocks.

We assume that the distribution of power, both before and after an aid shock, is known both to potential rebels and the government because potential rebels have strong incentives to obtain accurate assessments of state strength. Rebels are likely to watch government budgets closely, to the extent that they can, and they may monitor aid flows directly. Because the magnitude of aid shocks is large enough to shift the balance of power, rebels are likely to observe such shocks directly. At the very least, rebels indirectly observe aid shocks when governments provide fewer services or side-payments and when states spend less of the diverted aid on the military.

Large, rapid decreases in aid, though likely inadvertent, nevertheless upset the balance of power. ${ }^{6}$ Because aid is fungible (Feyzioglu, Swaroop, and Zhu 1998), a sudden withdrawal of aid reduces both the government's deterrent capacity and its ability to continue side-payments to rebels. This temporary government weakness increases the chance of rebel victory in the event of conflict, which allows rebels to demand more at the bargaining table. Thus, the size of the side-payments necessary to keep rebels indifferent between conflict and peace also increases.

This situation does not necessarily lead to conflict. Aid-induced shifts in the distribution of power could lead to bargaining over a new negotiated settlement that allows parties to avoid the high costs of war (Fearon 1995); war, after all, produces inefficient, Pareto-inferior outcomes (Powell 2006). That is, the spoils to be divided are larger before the war, even despite the shock to aid, than they would be afterwards-making a prewar settlement better for all potential combatants. Why, then, might aid shocks lead to war rather than a new agreement?

increases the likelihood of conflict (Kahl 2006; Nel and Righarts 2008). All of these types of shocks share a common dynamic in that they are discrete events with likely short-term consequences for a number of key political actors.

${ }^{6}$ Large shifts in aid flows-aid shocks in our parlance-are likely to result from changes in several factors rooted in aid allocation: the strategic importance of recipients to donors, recipient poverty, and recipient respect for political rights, among others (Alesina and Dollar 2000). Likewise, severe human rights violations have led donors to cancel all aid to certain recipients (Crawford 2001), and in our own data we find that the number of aid shocks increased in the years immediately following the collapse of the Soviet Union when some developing countries became less strategically important to Western donors.
We argue that aid shocks cause commitment problems (Fearon 1995; Powell 2004, 2006). Because deep aid cuts may shift the balance of power radically, rebels are likely to demand more resources than the government can provide in the short term. Thus, a promise of increased side-payments from the government to rebels often requires pledges drawing on future resources. But promises of future transfers are contingent on the newly realized balance of power, which favors the rebels. If aid flows resume, the government's newfound strength will likely embolden it to renege on its commitment, making its current promises of future transfers noncredible (Powell 2004, 236). Because the expected rebel payoff from conflict is probably greater than any offer the government can credibly announce, we argue that aid shocks heighten the probability of armed conflict.

Changes in the balance of power only induce a commitment problem if they require a deal to hold in the future as well as in the present. But most aid changes likely fall within a range where peaceful agreements are possible because the government can deliver the promised resources immediately. However, some aid changes are so large that the government will need several years (or more) to transfer enough resources to keep rebels from fighting. This creates a threshold effect-large changes in aid that push the balance of power over this threshold are categorically different from smaller aid changes. Thus, aid shocks are best conceptualized as essentially dichotomous: either an aid shock occurs, or it does not.

Hence, we arrive at our key hypothesis:

H1: Aid shocks-severe decreases in development finance revenues - will be associated with a higher likelihood of armed conflict.

Thus far, we have considered the effect of large decreases in aid, but positive aid shocks could also generate inefficient conflict because they may likewise engender commitment problems. Positive aid shocks shift the distribution of power to favor the government, reversing the situation described above. Again, both sides should try to reach an efficient solution that avoids war, which entails negotiating a new agreement reflecting the new distribution of power. Because the government is newly empowered, its bargaining position is enhanced, and it can demand a better deal with fewer concessions to rebels. However, if the positive aid shock is temporary, then the rebels will now have the incentive to renege on the deal once conditions return to normal. If the expected value to the government of fighting the rebels and possibly eliminating them is higher than what the rebels can credibly offer, then conflict will again break out. 
We note that other scholars have reached different conclusions. Fearon (2004), for example, argues that when the government is strong, incentives to rebel are minimized. Moreover, under abrupt aid increases, governments may fear that their use of the new resources to provoke conflict may lead donors to punish the aggressive regime with aid reductions in the future (see Berthelemy 2006). Additionally, positive aid windfalls increase the disparity between governments and potential rebels, which likely reduces uncertainty and hence dampens the propensity for violence (Reed 2003). Thus, since good theoretical reasons point in opposite directions for the effects of positive aid shocks, we leave the matter for empirical exploration.

Thus far, we have assumed that the distribution of power and aid flows are common knowledge, but some may doubt that rebels understand or follow flows of aid, making them uncertain about shifts in state strength. While we doubt that all aid flows are common knowledge, the assumption that both rebels and governments observe aid shocks is certainly plausible. If we nonetheless relax the common knowledge assumption, violent armed conflict can still arise from informational asymmetries, but through a different mechanism (e.g., Filson and Werner 2002; Slantchev 2003; Wagner 2000). Dal Bo and Powell (2009) offer one possible model for explaining why conflict might result if rebels are uncertain about the extent of aid shocks. Dal Bo and Powell model "spoils politics" in which the government and opposition compete to extract the rents available to those who run the state. Their model hinges on uncertainty about the size of the spoils; the overall balance of power is known, and both parties understand whether times are generally "good" or "bad," but rebels are uncertain over precisely how good or bad times really are. This uncertainty encourages the government to "lowball" its announcement of how large the spoils are during bad times, to which the rebels rationally respond by playing a strategy that includes violence at least some of the time. Uncertainty about the presence and depth of an aid shock is conceptually similar to the uncertainty about bad times that generates conflict in Dal Bo and Powell's model. ${ }^{7}$

Under incomplete information, rebels may not know the new distribution of power precisely, but generally they

${ }^{7}$ Although we prefer the complete information model that links aid shocks to conflict, we should be clear that our empirical analysis cannot decisively adjudicate between these two explanations. Perhaps the most decisive evidence to support the complete information explanation would be case-by-case evidence that rebels possess full information about aid flows and government budgets. It is our sense that this is the case, in part because rebels should have strong incentives to obtain this information, but data scarcity prevents us from bringing specific evidence to bear on this point. know that the government is experiencing "bad times." Because governments are typically stronger than rebels, an aid shock should move the government and rebels closer to parity in their capabilities. And uncertainty may be greatest when combatants are close to parity-a condition more likely following an aid shock than before the shock-making a war-averting agreement even less likely (Reed 2003). Thus, although an efficient solution should exist, both commitment and information problems make the inefficient outcome of violent armed conflict more likely after aid shocks.

It may be that some conflicts are best explained by the logic of commitment problems while others hew more closely to the dynamics of spoils politics under uncertainty. Both may also exist simultaneously—rebels may know that an aid shock shifts the distribution of power, which would lead to commitment problems, but the uncertainty about the size of the shift makes the terms of any war-averting resolution even more complicated. Regardless of mechanism, the common prediction is that aid shocks should be followed by an increased probability of bargaining failure and armed conflict onset. We now turn to an empirical evaluation of the aid shocks hypothesis.

\section{Data, Research Design, and Methodology}

Our dependent variable is armed conflict onset as coded in the UCDP/PRIO Armed Conflict Dataset (Gleditsch et al. 2002). ${ }^{8}$ In this dataset, conflicts are coded "1" if, in a given year, at least 25 battle deaths occurred between government forces and at least one rebel group. Otherwise, the observation is coded " 0 ." As in other studies of economic shocks and conflict (Elbadawi and Hegre 2004; Miguel, Satyanath, and Sergenti 2004), the lower death threshold means that we use information about the onset of conflicts that remain small along with those that eventually become large. ${ }^{9}$ In our primary specifications, we drop subsequent years of an ongoing conflict from the dataset but code resumed conflict as a new onset. ${ }^{10}$

${ }^{8}$ We restrict our examination to "internal" or "internationalized internal" armed conflicts as defined by Uppsala.

${ }^{9}$ Below, we consider small and large conflicts separately as part of our robustness analysis - the effects of aid shocks on the 46 conflicts with more than 1,000 deaths are still positive but significant only at the .1 level.

${ }^{10}$ In alternative specifications, we (1) include subsequent years of conflict in the dataset and (2) drop observations after the first onset of armed conflict in a country. The logic behind this second alternative is to be agnostic about whether later occurrences of armed 
We obtain information on foreign aid from AidData (Nielson et al. 2010), which offers a much-expanded accounting of the universe of aid flows-by nearly doubling the dollar amount to $\$ 4.2$ trillion-relative to the commonly used OECD database. Although we are using a new data source, we generally follow the OECD definition of Official Development Assistance (ODA) as grants and loans that are "undertaken by the official sector; with the promotion of economic development and welfare as the main objective; [and] on concessional financial terms" (OECD 2006). ${ }^{11}$ The data are recorded in project form; thus, we aggregate the aid flows to the country-year level.

We dichotomize our aid variable for theoretical reasons described above-we expect that peaceful equilibria will usually be robust to minor decreases in aid, but that major aid changes will upset these equilibria. To measure aid shocks, we begin by calculating the change in aid (standardized by GDP) for each country-year (aid/GDP aid/GDP $(-1) .{ }^{12}$ We average changes over the previous two years to account for the time gap between aid commitments and the time at which countries actually receive (or fail to receive) the aid. We elected not to use data on aid disbursements because the data before 2002 are too unreliable. ${ }^{13}$ Moreover, disbursements correlate closely with commitments (Neumayer 2003b, 43; Nielson and Tierney $2005,789) .{ }^{14}$

Using commitment data, we then define the bottom $15 \%$ of these aid changes to be Aid Shocks-negative

conflict are related to the first instance (Sambanis 2004), thus avoiding the sticky issue of deciding whether flare-ups in countries with conflicts are simply continuations of the previous conflict or are new conflicts. These alternative specifications produce qualitatively similar results (shown in the Supporting Information).

${ }^{11}$ Not all of the loans tracked by AidData would meet the strict OECD criteria of more than $25 \%$ grant, but many-and the vast majority since 2000 - would qualify as ODA. Nearly all AidData loans, however, are concessional in that they are generally offered to recipients at much lower interest rates than the countries could obtain using private financial markets.

${ }^{12}$ We standardize by recipient GDP because the importance of an aid decrease depends on the size of the economy. Using unstandardized aid dollars is probably inappropriate because losing $\$ 1$ million in aid matters more to countries with less income.

${ }^{13}$ AidData primarily gathers disbursement information from the OECD, which states that "analysis on CRS disbursements. . is not recommended for flows before 2002, because the annual coverage is below $60 \%$." Indeed, our comprehensive search of the data suggests that the availability is well below $60 \%$ for most donors for most years.

${ }^{14}$ In the supplementary information, we show results from a model using disbursement data between 2001 and 2005 (when available disbursement data are most reliable) that lends support to our hypothesis, but there are so few aid shocks and conflict onsets in this restricted sample that the results, while generally supportive, should be interpreted cautiously.

\section{FIGURE 1 Distribution of Changes in Aid}

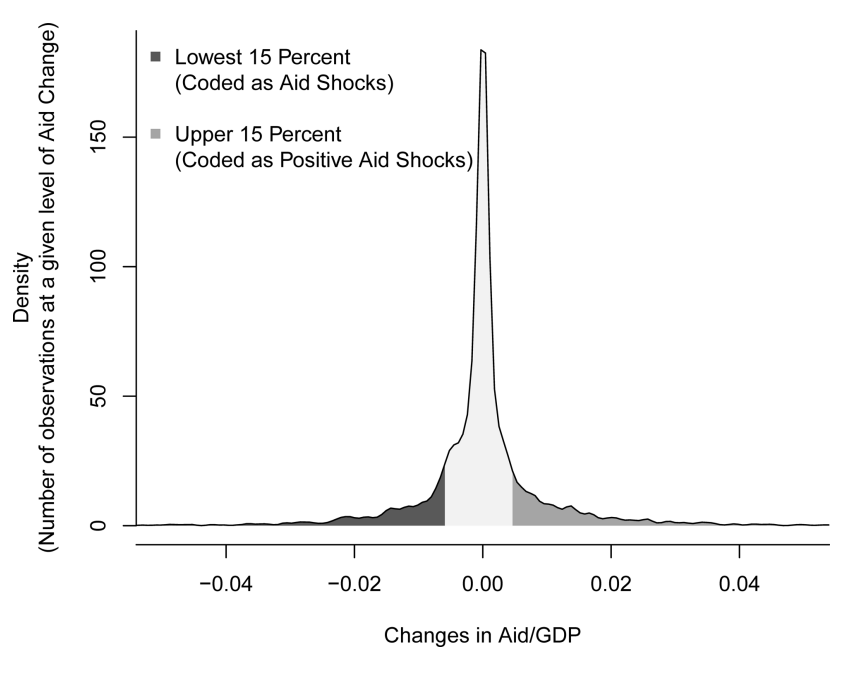

changes that are large enough that we expect them to have a potentially destabilizing effect on recipients. Setting the cutoff at the $15^{\text {th }}$ percentile is admittedly arbitrary, but, as we show below, the results are robust to multiple thresholds set between the $8^{\text {th }}$ and $25^{\text {th }}$ percentiles. Our definition of shocks corresponds to negative aid changes less than or equal to -0.0054 aid dollars per GDP dollar, or 54 cents per 100 dollars of GDP. ${ }^{15}$ Lest this appear paltry, we note that the average country in our sample receives 2.27 dollars of aid for every 100 dollars of GDP, so an aid decrease of 54 cents represents a $24 \%$ reduction on average. In the models below, we lag our indicator of aid shocks so that aid shocks in one year predict conflict in the next.

We also consider the possibility that positive aid shocks might lead to conflict by creating incentives for the government to try to crush the opposition while aid windfalls provide it more resources. Our measure of Positive Aid Shocks is constructed analogously to Aid Shocks, with the cutoff for a positive shock defined as changes in the two-year average of aid flows that are above the $85^{\text {th }}$ percentile of all such changes. The $85^{\text {th }}$ percentile cutoff for positive aid changes is 0.0052 , which corresponds to a positive aid change of at least $23 \%$. The distribution of aid changes, positive and negative, in our data is shown in Figure 1.

We illustrate the temporal distribution of aid shocks in Figure 2. It is particularly interesting that aid shocks increased somewhat following the end of the Cold War.

${ }^{15}$ This means that we code an aid shock when $\left[\left(\right.\right.$ aid $/ G D P_{t}-$ aid $\left./ G D P_{t-1}\right)+\left(\right.$ aid/GDP $\left.\left.P_{t-1}-\operatorname{aid} / G D P_{t-2}\right)\right] / 2=-.0054$. 


\section{FIGURE 2 Aid Shocks per Year}

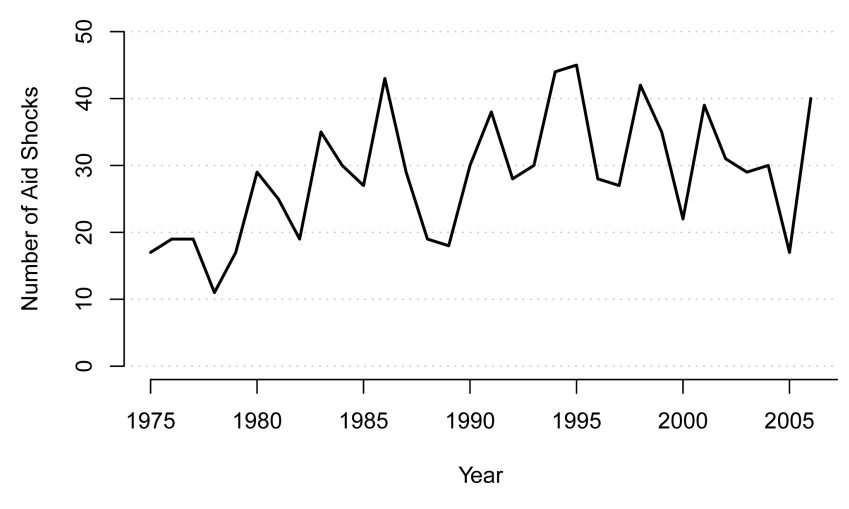

Donors may have attempted to secure a "peace dividend" by withdrawing the previously dominant strategic aid flows.

To account for potential confounding variables and to understand how aid shocks compare to other common predictors of armed conflict, we include a variety of control variables commonly used in the civil war literature (e.g., Blattman and Miguel 2009; Fearon and Laitin 2003; Sambanis 2004). These measures include ethnic fractionalization, religious fractionalization, oil exportation, instability, population, territorial contiguity, mountainous terrain, human rights violations, counts of assassinations, general strikes, riots, antigovernment demonstrations, infant mortality, an indicator for "bad neighborhoods" (the count of neighboring countries with a civil or ethnic conflict), an indicator for the Cold War period, a five-category measure of democracy (Goldstone et al. 2010), and GDP per capita as a measure of poverty, although we note that this has also been used as a proxy for weak states. To avoid posttreatment bias, all time-varying covariates are lagged by one year. ${ }^{16}$

Together, our time-series, cross-sectional dataset includes 139 countries from 1981 to $2005 .{ }^{17}$ The unit of analysis is the country-year. Because our outcome of interest is a dichotomous dependent variable-armed conflict onset or not-and it has few nonzero observations (approximately 3.5\%), we estimate a rare-events logistic regression model (King and Zeng 2001), pooling the 2,627 country-year observations together and using robust standard errors clustered by country.

\footnotetext{
${ }^{16}$ Operational details for all covariates appear in the Supporting Information, section A18.

${ }^{17}$ The time range of our analysis is based on the availability of certain control variables-when we omit these variables, we obtain similar results for 1975-2005.
}

\section{Empirical Results}

Beginning with a descriptive examination of the most severe aid shocks, we find support for the hypothesis that aid shocks lead to the outbreak of armed conflict. Of the 15 most severe negative aid shocks in our sample, four of the countries-Liberia (1999), Ghana (1981), Guinea-Bissau (1997), and Sierra Leone (1990)-experienced armed conflict within one year and Lesotho (1994) experienced violence within four years. ${ }^{18}$ With these cases offering preliminary if anecdotal support, we turn to more rigorous statistical analyses.

Our primary empirical results appear in Table 1. In Model 1, we find strong support for our hypothesis that aid shocks are correlated with an increased risk of armed conflict $(b=0.91, \mathrm{p}=0.001)$. Substantively, if the average country were to experience an aid shock with other factors remaining constant, the risk of violent conflict more than doubles, from $2.1 \%$ to $5.0 \%$. In contrast, we find no evidence that positive aid shocks substantially increase the probability of conflict $(b=0.15, \mathrm{p}=0.67)$. A formal F-test rejects the null hypothesis that the coefficients on Aid Shocks and Positive Aid Shocks are the same ( $\mathrm{p}=$ 0.036).

Turning to other determinants of civil conflict, we find that human rights violations, factional democracy, oil production, ethnic fractionalization, and noncontiguity are all associated with a higher risk of violent conflict. Perhaps surprisingly, we find that in the presence of the other controls, GDP per capita, population, and mountainous terrain have no apparent effect (in agreement with Goldstone et al. [2010]), although it is probably inappropriate to interpret the coefficients for any of the control variables causally because the model is designed primarily to estimate the causal effect of aid shocks.

Our argument predicts that a single country that experiences an aid shock will have a higher probability of armed conflict, but the rare-events logit relies on crosssectional variation as well as within-country variation (Wilson and Butler 2007). To show that our findings regarding Aid Shocks hold within countries as well as between them, we estimate a conditional logistic regression with fixed effects for each panel to effectively limit the inferential leverage to within-country variation. This directly tests the hypothesis that an aid shock to a particular country increases the probability of onset for that country. We obtain strikingly similar results: the presence of an aid shock correlates with an increased probability of conflict $(b=0.91, \mathrm{p}=0.010)$. This indicates that unobserved

\footnotetext{
${ }^{18}$ Of the 25 worst aid shocks, 7 (28\%) were followed by internal
} conflict within three years. 
TABLE 1 Models of the Onset of Civil Conflict

\begin{tabular}{|c|c|c|c|c|}
\hline & $\begin{array}{c}(1) \\
\text { Rare-Events } \\
\text { Logit }\end{array}$ & $\begin{array}{c}(2) \\
\text { Fixed Effects } \\
\text { Logit }\end{array}$ & $\begin{array}{c}(3) \\
\text { Propensity Score } \\
\text { Matching }\end{array}$ & $\begin{array}{c}\text { (4) } \\
\text { Genetic Matching }\end{array}$ \\
\hline Aid Shock & $\begin{array}{l}0.911^{* * *} \\
(0.277)\end{array}$ & $\begin{array}{l}0.910^{* * *} \\
(0.353)\end{array}$ & $\begin{array}{l}0.934^{* * *} \\
(0.318)\end{array}$ & $\begin{array}{c}0.999^{* *} \\
(0.388)\end{array}$ \\
\hline Positive Aid Shock & $\begin{array}{c}0.154 \\
(0.363)\end{array}$ & $\begin{array}{r}-0.0938 \\
(0.406)\end{array}$ & & \\
\hline Human Rights Violations & $\begin{array}{l}0.607^{* * *} \\
(0.140)\end{array}$ & $\begin{array}{l}0.537^{* * *} \\
(0.205)\end{array}$ & $\begin{array}{l}0.584^{* * *} \\
(0.213)\end{array}$ & $\begin{array}{c}0.396^{*} \\
(0.232)\end{array}$ \\
\hline Assassinations & $\begin{array}{c}0.136 \\
(0.0985)\end{array}$ & $\begin{array}{c}0.170 \\
(0.136)\end{array}$ & $\begin{array}{r}-0.295 \\
(0.554)\end{array}$ & $\begin{array}{r}-0.0173 \\
(0.242)\end{array}$ \\
\hline Riots & $\begin{array}{c}0.0136 \\
(0.130)\end{array}$ & $\begin{array}{r}-0.194 \\
(0.165)\end{array}$ & $\begin{array}{l}0.000669 \\
(0.178)\end{array}$ & $\begin{array}{c}0.211 \\
(0.130)\end{array}$ \\
\hline General Strikes & $\begin{array}{c}0.0148 \\
(0.212)\end{array}$ & $\begin{array}{c}0.558^{*} \\
(0.301)\end{array}$ & $\begin{array}{c}0.182 \\
(0.280)\end{array}$ & $\begin{array}{c}0.361^{*} \\
(0.210)\end{array}$ \\
\hline Antigov. Demonstrations & $\begin{array}{c}-0.0526 \\
(0.124)\end{array}$ & $\begin{array}{r}-0.0959 \\
(0.122)\end{array}$ & $\begin{array}{c}0.0497 \\
(0.110)\end{array}$ & $\begin{array}{c}0.0263 \\
(0.142)\end{array}$ \\
\hline Infant Mortality & $\begin{array}{c}0.00343 \\
(0.00478)\end{array}$ & $\begin{array}{r}-0.0159 \\
(0.0199)\end{array}$ & $\begin{array}{r}-0.00001 \\
(0.00658)\end{array}$ & $\begin{array}{c}0.00678 \\
(0.00688)\end{array}$ \\
\hline Bad Neighborhood & $\begin{array}{c}-0.0381 \\
(0.118)\end{array}$ & $\begin{array}{r}-0.0469 \\
(0.203)\end{array}$ & $\begin{array}{c}-0.0272 \\
(0.183)\end{array}$ & $\begin{array}{l}0.00617 \\
(0.207)\end{array}$ \\
\hline Partial Autocracy & $\begin{array}{c}0.230 \\
(0.333)\end{array}$ & $\begin{array}{c}0.302 \\
(0.556)\end{array}$ & $\begin{array}{c}0.363 \\
(0.444)\end{array}$ & $\begin{array}{c}0.152 \\
(0.434)\end{array}$ \\
\hline Partial Democracy & $\begin{array}{r}-0.669 \\
(0.472)\end{array}$ & $\begin{array}{c}-0.0239 \\
(0.795)\end{array}$ & $\begin{array}{r}-0.792 \\
(0.662)\end{array}$ & $\begin{array}{r}-0.770 \\
(0.629)\end{array}$ \\
\hline Factional Democracy & $\begin{array}{c}0.681^{*} \\
(0.385)\end{array}$ & $\begin{array}{l}1.565^{* *} \\
(0.651)\end{array}$ & $\begin{array}{c}0.738 \\
(0.515)\end{array}$ & $\begin{array}{c}0.498 \\
(0.564)\end{array}$ \\
\hline Full Democracy & $\begin{array}{c}0.176 \\
(0.547)\end{array}$ & $\begin{array}{c}1.133 \\
(1.210)\end{array}$ & $\begin{array}{c}0.139 \\
(1.077)\end{array}$ & $\begin{array}{c}0.872 \\
(0.743)\end{array}$ \\
\hline $\ln ($ GDP per capita) & $\begin{array}{r}-0.200 \\
(0.238)\end{array}$ & $\begin{array}{r}-0.573 \\
(0.773)\end{array}$ & $\begin{array}{r}-0.341 \\
(0.327)\end{array}$ & $\begin{array}{r}-0.264 \\
(0.293)\end{array}$ \\
\hline $\ln$ (Population) & $\begin{array}{c}0.0902 \\
(0.0839)\end{array}$ & $\begin{array}{c}-2.467 \\
(1.905)\end{array}$ & $\begin{array}{c}0.0110 \\
(0.176)\end{array}$ & $\begin{array}{r}-0.0833 \\
(0.216)\end{array}$ \\
\hline Oil & $\begin{array}{l}0.00989^{* * *} \\
(0.00299)\end{array}$ & $\begin{array}{c}0.00610 \\
(0.00867)\end{array}$ & $\begin{array}{c}0.0288 \\
(0.0646)\end{array}$ & $\begin{array}{c}0.0106 \\
(0.0783)\end{array}$ \\
\hline Instability & $\begin{array}{c}0.225 \\
(0.272)\end{array}$ & $\begin{array}{r}0.0587 \\
(0.373)\end{array}$ & $\begin{array}{c}0.236 \\
(0.360)\end{array}$ & $\begin{array}{c}0.238 \\
(0.441)\end{array}$ \\
\hline Ethnic Frac. & $\begin{array}{l}1.341^{* *} \\
(0.585)\end{array}$ & & $\begin{array}{r}-0.145 \\
(1.088)\end{array}$ & $\begin{array}{r}-0.299 \\
(1.248)\end{array}$ \\
\hline Religious Frac. & $\begin{array}{c}-0.738 \\
(0.673)\end{array}$ & & $\begin{array}{r}-0.201 \\
(1.301)\end{array}$ & $\begin{array}{c}0.357 \\
(1.325)\end{array}$ \\
\hline Noncontiguous & $\begin{array}{l}0.985^{* * *} \\
(0.317)\end{array}$ & & & $\begin{array}{c}0.268 \\
(0.661)\end{array}$ \\
\hline Mountains & $\begin{array}{c}0.0863 \\
(0.0941)\end{array}$ & & $\begin{array}{c}-0.0476 \\
(0.130)\end{array}$ & $\begin{array}{r}-0.116 \\
(0.142)\end{array}$ \\
\hline Cold War & $\begin{array}{c}0.163 \\
(0.285)\end{array}$ & $\begin{array}{r}-0.650 \\
(0.549)\end{array}$ & $\begin{array}{r}-0.222 \\
(0.501)\end{array}$ & $\begin{array}{r}-0.0759 \\
(0.473)\end{array}$ \\
\hline
\end{tabular}


TABLE 1 Continued

\begin{tabular}{lcccc}
\hline & $\begin{array}{c}(\mathbf{1}) \\
\text { Rare-Events } \\
\text { Logit }\end{array}$ & $\begin{array}{c}(\mathbf{2}) \\
\text { Fixed Effects } \\
\text { Logit }\end{array}$ & $\begin{array}{c}(3) \\
\text { Propensity Score } \\
\text { Matching }\end{array}$ & Genetic Matching \\
\hline Constant & $-5.797^{* *}$ & & -1.914 & -1.529 \\
& $(2.899)$ & & $(4.210)$ & $(4.243)$ \\
Observations & 2627 & 953 & 786 & 698 \\
Number of Countries & 139 & 57 & 103 & 86 \\
\hline
\end{tabular}

Note: Model 1 includes a correction for rare-events bias. Model 2 includes country-level fixed effects. Model 3 uses one-to-one propensity score matching followed by rare-events logit on the matched sample. Model 4 uses genetic matching followed by rare-events logit. Robust standard errors are in parentheses. Standard errors in Models 1, 3, and 4 are clustered by country. Cubic splines are included but not reported. ${ }^{* * *} \mathrm{p}<0.01,{ }^{* *} \mathrm{p}<0.05,{ }^{*} \mathrm{p}<0.1$.

heterogeneity between countries is not confounding our results and suggests that the effects we identify operate at the country level as predicted.

\section{Matching and the Effect of Aid Shocks}

Our logistic regression will only provide valid causal estimates of the effect of aid shocks on conflict onset if there is no endogeneity, meaning that aid shocks occur as if at random after conditioning on the covariates included in the model. The primary threat of endogeneity arises from the possibility that donors anticipate armed conflict and reduce aid in anticipation of impending violence. We are somewhat skeptical that this endogeneity problem exists because it is unlikely that donors anticipate even high levels of violence. Accurate early warning systems have proven very difficult to develop, with current models often failing to predict both armed conflict occurrence and magnitude (Jenkins and Bond 2001). In Kenya, for example, the postelection violence in early 2008 was almost universally unexpected, and yet it reached very high levels of deaths (thousands) over a short period of time.

Could the expectation of conflict induce aid shocks? Some studies have found that aid decreases when states violate human rights, and these violations may be precursors to violent conflict (Carey 2007; Cingranelli and Pasquarello 1985; but see Neumayer 2003a). Moreover, there is evidence that past internal conflict leads to subsequent decreases in aid flows (Berthelemy 2006). However, we know of no direct evidence that the anticipation of conflict leads to aid decreases, and prior studies of aid allocation in contexts as diverse as Rwanda, El Salvador, Sri Lanka, and Angola suggest that this may be unlikely (Chauvet 2003; Muscat 2002, 53; Uvin 1998). Nevertheless, we have attempted to model donors' anticipation of armed conflict as a potential cause of aid shocks in the matching analysis we develop below.

Out of concern that endogeneity biases our findings, we use matching methods designed for causal inference in observational studies to provide further support that our finding is causal. Although matching has many attractive qualities, we should be clear that this method relies on conditioning on observed variables-we cannot rule out the possibility that some unobserved confounder biases our findings. We attempt to minimize this risk by carefully considering the likely confounders and making extra effort to measure them carefully and thoroughly. ${ }^{19}$

Matching methods attempt to fix the "broken" experiment presented by observational data. In our pooled sample, we might suspect that countries experiencing aid shocks are very different from most countries that do not have aid shocks, and that these differences, not the aid shocks themselves, are the actual causes of any correlation we observe between aid shocks and conflict. Matching solves this problem by discarding these drastically different observations and comparing "like to like" (similar to a randomized experiment). ${ }^{20}$

\footnotetext{
${ }^{19}$ We also attempted to find a source of exogenous variation-a natural experiment - that would give us a valid instrumental variable for aid shocks. The instrumental variable (IV) approach is attractive because a valid instrument allows causal inference in the face of observed and unobserved confounding factors. We tried a number of potential instruments culled from the aid allocation literature, including recipient membership on the United Nations Security Council, fluctuations in donor GDP, and voting similarity in the United Nations General Assembly. We eventually rejected all three as invalid either because they likely fail the exclusion restriction or because they are not significantly correlated with aid shocks (we provide a full description of our reasoning and procedures in the Supporting Information). With no plausible natural experiment, we turn to matching as a next-best solution.

${ }^{20}$ Estimating causal effects via matching requires the stable unit
treatment value assumption (SUTVA), which necessitates that each
observation's potential outcomes are independent (Rubin 1986).
} 
Matching relies crucially on our ability to observe, measure, and condition on the variables that induce endogeneity between aid shocks and conflict. Unfortunately, the key variable that might induce endogeneity-the expectation of future conflict in the minds of policymakers allocating foreign aid-is unobservable. However, we can still address the concern by measuring and conditioning on the factors that are most likely to influence donor expectations. We argue that expectations about the potential for conflict onset are based primarily on a country's level of democracy, its record of human rights protection, its income and standard of living, and early indications of conflict onset such as civil unrest. We draw some of these variables directly from recent work by Goldstone et al. (2010) that predicts the onset of political instability with $80 \%$ accuracy: a five-category measure of democracy based on Polity IV scores, a measure of infant mortality, and a measure of "bad neighborhoods"-the count of neighboring countries that are experiencing civil conflict. ${ }^{21}$ We also include measures of "simmering" violence: counts of riots, assassinations, antigovernment demonstrations, and general strikes, as well as a measure of human rights violations.

We then use matching methods to create a matched sample from our original sample, consisting of the "treated" country-years (Aid Shock $=1)$ and a subset of the "control" country-years (Aid Shock $=0)$ that have the same levels of these covariates, making them similarly likely to have conflict in the absence of an aid shock. We reestimate our original model on this matched subsample to estimate the causal effect of aid shocks on conflict onset.

Of the many available matching methods, we use two: one-to-one propensity score matching (Rosenbaum and Rubin 1983) and genetic matching (Diamond and Sekhon 2006; Sekhon forthcoming). Propensity score matching is conceptually similar to a selection model: we first estimate a logistic regression predicting aid shocks using all of the control variables listed above as matching covariates along with country-level random intercepts. The results of this model (shown in the Supporting Information) indicate that, in the unmatched data, country-years

Although this is difficult to satisfy in most international relations settings, this assumption is more likely to be satisfied in our case because aid shocks occur relatively independently from year to year and from country to country-in contrast with other "treatments" such as democracy.

${ }^{21}$ We omit the variable state discrimination against minorities used by Goldstone et al. (2010). Including this variable without imputation reduces our data coverage substantially. The results with this covariate included are similar to those reported in the main findings. that experience aid shocks have significantly more human rights violations; are more likely to be a partial autocracy, partial democracy, or full democracy (relative to the base category of full autocracy); and have lower income and smaller populations. From this model, we generate predicted values that serve as propensity scores - the estimated probability that a given country-year will have an aid shock.

We then match each treated observation (Aid Shock $=1$ ) to the control observation (Aid Shock $=0$ ) with the most similar propensity score. We find a one-to-one match for each of the 393 aid shocks in the dataset; per standard matching best practice, the 1,841 unmatched control units are dropped from the dataset. Despite substantial differences between treated and control units in the original data, our matching algorithm achieves a remarkable degree of balance on these covariates, limiting the control cases to a set that looks almost identical to country-years that experience aid shocks. In particular, we dramatically improve the balance of several likely confounders: human rights, GDP, population, and levels of democracy (for more detail, see Supporting Information-Appendix A17).

If matching is exact, then the causal effect of Aid Shock is simply the difference in Conflict between the treatment and control groups. Our matching is not exact due to the continuous nature of some of our variables and large preexisting differences between treatment and control groups, so we follow the suggestion of Ho et al. (2007) and estimate our original model ${ }^{22}$ on this matched subsample, similar to the second stage of a selection model. We retain all of the treated observations but exclude many of the dissimilar control units. Our model then estimates the average treatment effect on the treated-the effect of aid shocks in those states that experience them.

Column 3 of Table 1 presents the findings of our propensity score analysis. We first note that, after matching, only the coefficient of the treatment variable can be interpreted causally. We find that the estimated causal effect of experiencing an aid shock after matching is virtually identical to the estimated effect without matching shown in Model $1(b=0.93, \mathrm{p}=0.003)$, suggesting that the effects of aid shocks estimated by our initial model are indicative of a genuine causal relationship.

We then attempt to improve on propensity score matching by using the genetic matching algorithm developed by Diamond and Sekhon (2006) to create a dataset of matched treatment and control observations that evinces better covariate balance. Genetic matching uses a genetic

\footnotetext{
${ }^{22}$ We omit Positive Aid Shock from the matching models because it is not a proper pretreatment covariate.
} 
algorithm to directly maximize the distributional similarity of the covariates. As expected, we find large improvements in the overall balance of the covariates, and we are able to provide slightly better balance on several covariates (see Supporting Information for more detail). As with propensity score matching, we estimate the causal effect of Aid Shocks by fitting the original logistic regression to the matched dataset. The results are entirely consistent with our previous findings, improving our confidence that the relationship between aid shocks and conflict onset is likely causal (see Table 1, Model 4).

\section{Robustness}

Robustness checks further improve our confidence in the findings. Using a dependent variable that includes only the first conflict onset (to avoid potentially misclassifying temporary lapses in violence as independent conflicts), we find that Aid Shocks still lead to an increased probability of conflict ( $b=1.13, \mathrm{p}=0.008$ ). When we include only the onset of the 46 wars that eventually reach 1,000 battle deaths, our results are shy of statistical significance at the .05 level $(b=0.66, \mathrm{p}=0.069)$, so we conclude that aid shocks are less predictive of large conflict onset.

Alternative operationalizations of our primary independent variable Aid Shocks - the percentile cutoff to be considered an aid shock, the number of aid shocks in any five-year period, and a continuous measure of aid change-give further insights into the effects of aid changes on conflict. We find that our results are similar with aid shocks defined as the lowest $25 \%$ of aid changes $(b=0.48, \mathrm{p}=0.051)$, as the lowest $20 \%(b=0.79, \mathrm{p}=$ $0.001)$, and as the lowest $10 \%(b=0.78, \mathrm{p}=0.016)$ compared to the $15 \%$ cutoff in the baseline analysis. Figure 3 shows the coefficients that result from varying the cutoff for aid shocks. The results hold for a variety of definitions of aid shocks-we could have defined aid shocks as narrowly as the most negative $8 \%$ of aid changes or as broadly as the most negative $25 \%$ of aid changes. ${ }^{23}$ Similar results also were produced when we used the average number of aid shocks in the previous five years to predict the onset of violent conflict $(b=1.96, \mathrm{p}=0.013)$.

We have argued above that it is more appropriate to measure aid shocks rather than simply estimate the linear

\footnotetext{
${ }^{23}$ These results depend in part on how sustained are the aid shocks. The baseline models use a two-year rolling average of negative changes in aid. The results using an Aid Shock variable based only on the previous year's aid changes are significant only at the .1 level $(b=0.50, \mathrm{p}=0.079)$, suggesting that aid shocks have greater effects when they span multiple years.
}

\section{FigurE 3 The Estimated Effect of Aid Shocks with Different Cutoffs}

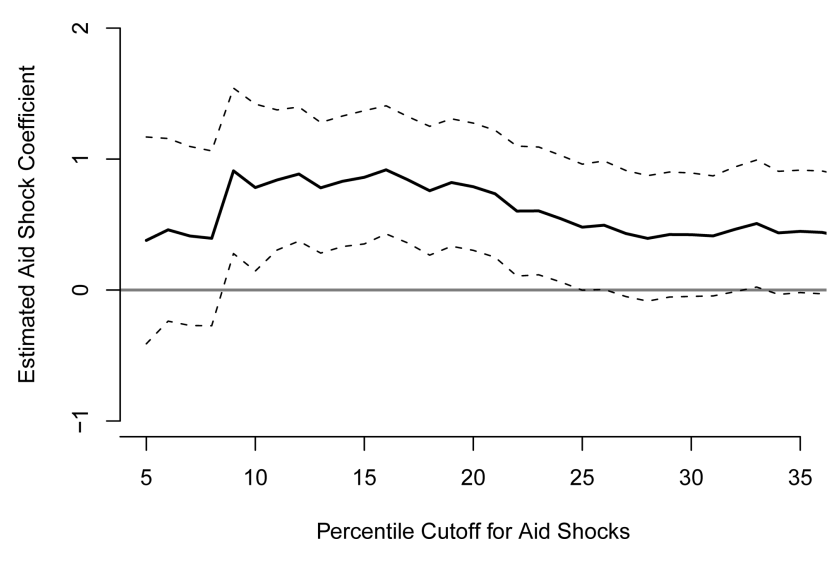

effect of any aid change on conflict onset. Our findings depend on this argument; we find that continuous measures of aid change affect the probability of conflict onset in the expected direction but that the result is not statistically significant (see the Supporting Information). We thus make no claims that changes in aid affect conflict onset linearly or incrementally. Our argument and evidence only support the conclusion that exceptionally large aid decreases cause conflict, which is consistent with the credible commitment logic (Powell 2004).

To account for missing observations (we lose 811 country-years from list-wise deletion), we use multiple imputation (Honaker, King, and Blackwell 2005), which imputes the missing data using covariates to estimate multiple datasets with different values. When we impute the missing observations and estimate the models using the multiple datasets in tandem to preserve the uncertainty of the missing data, we still find that Aid Shocks are substantively and statistically significant $(b=0.58, \mathrm{p}=0.005)$.

Although we used cubic splines as advocated by Beck, Katz, and Tucker (1998), we also considered polynomials of time (time, time ${ }^{2}$, and time ${ }^{3}$ ) to account for time trends as suggested by Carter and Signorino (2010) and obtained similar findings. A nonparametric panel bootstrap that adjusts our standard errors yields the same conclusions. Anticipating concerns related to bias from the spike in civil wars following the Soviet breakup (e.g., Hewitt, Wilkenfeld, and Gurr 2008), we find that our results are robust to excluding the years 1991-96 from the analysis, and the estimated effect of Aid Shocks is even larger after the exclusion $(b=1.10, \mathrm{p}=0.002)$. 


\section{Why Do Positive Aid Shocks Fail to Cause Conflict?}

Our findings show with some conclusiveness that negative aid shocks increase the probability of conflict onset while positive aid shocks do not. Although both negative and positive shocks may increase the probability of conflict relative to no shock, the estimated effect of positive shocks is relatively small and statistically insignificant. How does this result square with the possibility that both positive and negative shocks should generate uncertainty and result in similar commitment problems?

It could be that the general commitment problem logic outlined by Powell $(2004,2006)$ does not apply to positive shocks for some reason. One possibility is that negative and positive shocks have differential effects because the distribution of power typically heavily favors the government over the rebels. Formal results by Reed (2003) suggest that when there is information asymmetry about the other parties' reservation value, conflict is most likely as the players reach parity, meaning that negative aid shocks cause conflict because they increase parity while positive shocks reduce conflict because they reduce parity. However, this logic departs significantly from the logic of commitment problems and does not explain why the coefficient on Positive Aid Shocks is positive rather than negative.

It could also be the case that governments do not seek to lock in their advantage for other reasons, or that they seek to lock in their advantage through means such as quiet repression short of war. Higher levels of aid are only maintained at the behest of foreign aid donors that can easily take them away-and evidence indicates that donors withhold aid when governments provoke conflict (Berthélemy 2006). ${ }^{24}$ Foreseeing this, governments may exercise restraint, and rebels might also perceive the government's commitment as credible.

However, this raises a wrinkle: if rebels know that donors will punish governments for renewed war, then rebels have an incentive to bait the government into violence (Kuperman 2008). But three factors mitigate this possibility. First, rebels' incentives to provoke government violence primarily hold under normal aid conditions, when a future decrease should advantage the rebels. However, in the face of a positive aid shock, rebels face a significantly strengthened government opponent in the short run, likely inducing rebel restraint. Second, donors may be able to identify rebels as the provokers of violence

\footnotetext{
${ }^{24}$ Note that donors may not be able to anticipate future violence and cut off aid allocations; instead, they are better able to monitor government behavior and punish actual violations reactively.
}

and may come to their allies' aid with increased payments, which would further disadvantage rebels. And finally, any future decreases in aid revenue also decrease the size of the spoils to be won from rebellion, thus potentially having offsetting effects on the probability of violence.

\section{Conclusion}

Our results suggest that aid can affect the likelihood of violent armed conflict primarily by influencing a state's ability to credibly commit to an agreement that averts war at present and into the future. For aid recipients, sudden aid shortfalls make governments relatively less able to make enough side-payments or military investment to preserve the peaceful status quo in the future. Our findings contribute to the literature on foreign aid and armed conflict in important ways. In contrast to studies finding only an indirect connection between levels of foreign aid and armed conflict (Collier and Hoeffler 2002), we find a direct connection between changes in aid and conflict. To explore this, we used data on aid flows to countries from 1981 to 2005.

In addition to the theoretical implications, significant policy implications also flow from our analysis. First, the finding that aid shocks precipitate armed conflict ought to give policymakers pause as they contemplate shifts in their aid portfolios. It also may enhance donors' incentives to coordinate aid with other donors. Indeed, in recent years the calls for better aid coordination have intensified, and our results provide some evidence that such coordination is warranted. Our findings indicate that, if donors decide to remove aid, they should do so gradually over time because sudden large decreases in aid could be deadly. Although considerable debate still exists about the effectiveness of foreign aid, our analysis suggests that changes in aid, in addition to levels of aid, are potentially very important determinants of violent conflict, so we recommend that donors take whatever measures they can to prevent sudden aid withdrawals.

\section{References}

Agénor, Pierre-Richard, and Joshua Aizenman. 2010. "Aid Volatility and Poverty Traps.” Journal of Development Economics 91(1): 1-7.

Alesina, Alberto, and David Dollar. 2000. "Who Gives Foreign Aid to Whom and Why?" Journal of Economic Growth 5(1): 33-63.

Arcand, Jean-Louis, and Lisa Chauvet. 2001. "Foreign Aid, Rent-Seeking Behavior, and Civil War." Presented at 
Understanding Poverty and Growth in Sub-Saharan Africa, Oxford.

Azam, Jean-Paul. 1995. "How to Pay for the Peace? A Theoretical Framework with References to African Countries." Public Choice 83 (1/2): 173-84.

Azam, Jean-Paul. 2001. "Civil War and the Social Contract." Public Choice 115(3/4): 455-75.

Beck, Neal, Jonathan N. Katz, and Richard Tucker. 1998. “Taking Time Seriously: Time-Series Cross-Section Analysis with a Binary Dependent Variable." American Journal of Political Science 42(4): 1260-88.

Berthelemy, Jean-Claude. 2006. "Bilateral Donors' Interest vs. Recipients' Development Motives in Aid Allocation: Do All Donors Behave the Same?" Review of Development Economics 10(2): 179-94.

Blattman, Christopher, and Edward Miguel. 2009. "Civil War." Journal of Economic Literature 48(1): 3-57.

Bulir, Ales, and A. Javier Hamann. 2003. "Aid Volatility: An Empirical Assessment.” IMF Staff Papers 50(1): 64-89.

Bulır, Ales, and A. Javier Hamann. 2006. "Volatility of Development Aid: From the Frying Pan into the Fire?" IMF Working Paper 06/65: 7.

Carey, Sabine C. 2007. "European Aid: Human Rights versus Bureaucratic Inertia?” Journal of Peace Research 44(4): 447-64.

Carter, David B., and Curt S. Signorino. 2010. "Back to the Future: Modeling Time Dependency in Binary Data." Political Analysis 18(3): 271-92.

Chauvet, Lisa. 2003. "Socio-political Instability and the Allocation of International Aid by Donors." European Journal of Political Economy 19(1): 33-59.

Cingranelli, David L., and Thomas E. Pasquarello. 1985. "Human Rights Practices and the Distribution of US Foreign Aid to Latin American Countries." American Journal of Political Science 29(3): 539-63.

Collier, Paul. 1999. “Aid 'Dependency': A Critique.” Journal of African Economies 8(4): 528-45.

Collier, Paul, and Anke Hoeffler. 2002. "Aid, Policy, and Peace: Reducing the Risks of Civil Conflict." Defense and Peace Economics 13(6): 435-50.

Collier, Paul, and Anke Hoeffler. 2007. "Unintended Consequences: Does Aid Promote Arms Races?” Oxford Bulletin of Economics and Statistics 69(1): 1-27.

Crawford, Gordon. 2001. Foreign Aid and Political Reform: A Comparative Analysis of Democracy Assistance and Political Conditionality. New York: Palgrave.

Dal Bó, Ernesto, and Robert Powell. 2009. "A Model of Spoils Politics.” American Journal of Political Science 53(1): 20722.

Dang, Hai-Anh, Steve Knack, and F. Halsey Rogers. 2010. "International Aid and Financial Crises in Donor Countries." World Bank Policy Research Working Paper 5162: 1-37.

De Ree, Joppe, and Eleonara Nillesen. 2009. “Aiding Violence or Peace? The Impact of Foreign Aid on the Risk of Civil Conflict in Sub-Saharan Africa." Journal of Development Economics 88(2): 301-13.

Diamond, Alexis, and Jasjeet Sekhon. 2006. "Genetic Matching for Estimating Causal Effects: A General Multivariate
Matching Method for Achieving Balance in Observational Studies." Presentation to the Institute of Government, University of California, Berkeley.

Eifert, Benn, and Alan Gelb. 2005. "Coping with Aid Volatility." Finance and Development 42(3): 24-27.

Elbadawi, Ibrahim, and Havard Hegre. 2004. "Globalization, Economic Shocks, and Armed Conflict." Presented at the Conference on Globalization, Territoriality and Conflict, San Diego.

Esman, Milton J., and Ronald J. Herring. 2003. Carrots, Sticks, and Ethnic Conflict: Rethinking Development Assistance. Ann Arbor: University of Michigan Press.

Fearon, James D. 1995. "Rationalist Explanations for War." International Organization 49(3): 379-414.

Fearon, James D. 2004. "Why Do Some Civil Wars Last So Much Longer Than Others?" Journal of Peace Research 41(3): 275-302.

Fearon, James D., and David Laitin. 1996. "Explaining Interethnic Cooperation.” American Political Science Review 90(4): 715-35.

Fearon, James D., and David Laitin. 2003. "Ethnicity, Insurgency, and Civil War." American Political Science Review 97(1): 75-90.

Feyzioglu, Tarhan, Vinaya Swaroop, and Min Zhu. 1998. "A Panel Data Analysis of the Fungibility of Foreign Aid.” World Bank Economic Review 12(1): 29-58.

Filson, Darren, and Suzanne Werner. 2002. "A Bargaining Model of War and Peace: Anticipating the Onset, Duration, and Outcome of War." American Journal of Political Science 46(4): 819-38.

Gleditsch, Nils Petter, Peter Wallensteen, Mikael Eriksson, Margareta Sollenberg, and Håvard Strand. 2002. "Armed Conflict 1946-2001: A New Dataset.” Journal of Peace Research 39(5): 615-37.

Goldstone, Jack A., Robert H. Bates, David L. Epstein, Ted Robert Gurr, Michale B. Lustik, Monty G. Marshall, Jay Ulfelder, and Mark Woodward. 2010. "A Global Model for Forecasting Political Instability.” American Journal of Political Science 54(1): 190-208.

Grossman, Herschel I. 1991. "A General Equilibrium Theory Model of Insurrections." American Economic Review 81(4): 912-21.

Grossman, Herschel I. 1992. "Foreign Aid and Insurrection." Defense Economics 3(4): 275-88.

Hewitt, Joseph, Jonathan Wilkenfeld, and Ted Robert Gurr. 2008. Peace and Conflict 2008. Boulder, CO: Paradigm.

Ho, Daniel E., Kosuke Imai, Gary King, and Elizabeth A. Stuart. 2007. "Matching as Nonparametric Preprocessing for Reducing Model Dependence in Parametric Causal Inference." Political Analysis 15(3): 199-236.

Honaker, James, Gary King, and Matthew Blackwell. 2005-2008. "Amelia II: A Program for Missing Data." http://gking.harvard.edu/amelia (accessed September 11, 2008).

Imperato, Pascal James. 1989. Mali: A Search for Direction. Boulder, CO: Westview Press.

Jenkins, J. Craig, and Doug Bond. 2001. "Conflict-Carrying Capacity, Political Crisis, and Reconstruction: A Framework 
for the Early Warning of Political System Vulnerability." Journal of Conflict Resolution 45(3): 3-31.

Kahl, Colin. 2006. States, Scarcity, and Civil Strife in the Developing World. Princeton, NJ: Princeton University Press.

King, Gary, and Langche Zeng. 2001. "Logistic Regression in Rare Events Data." Political Analysis 9(2): 137-63.

Kuperman, Alan J. 2008. "The Moral Hazard of Humanitarian Intervention: Lessons from the Balkans.” International Studies Quarterly 52(1): 49-80.

Kuziemko, Ilyana, and Eric Werker. 2006. "How Much Is a Seat on the Security Council Worth? Foreign Aid and Bribery at the United Nations." Journal of Political Economy 114(5): 905-30.

Lai, Brian. 2003. "Examining the Goals of US Foreign Assistance in the Post-Cold War Period, 1991-96." Journal of Peace Research 40(1): 103-28.

Lebovic, James H. 1988. "National Interests and U.S. Foreign Aid: The Carter and Reagan Years." Journal of Peace Research 25(2): 115-32.

Lensink, Robert, and Oliver Morrisey. 2000. “Aid Instability as a Measure of Uncertainty and the Positive Impact of Aid on Growth.” Journal of Development Studies 36(3): 31-49.

McKinlay, Robert, and Richard Little. 1977. "A Foreign Policy Model of U.S. Bilateral Aid Allocation.” World Politics 30(1): 58-86.

Meernik, James, Eric L. Krueger, and Steven C. Poe. 1998. “Testing Models of U.S. Foreign Policy: Foreign Aid During and After the Cold War." Journal of Politics 60(1): 63-85.

Miguel, Edward, Shanker Satyanath, and Ernest Sergenti. 2004. "Economic Shocks and Civil Conflict: An Instrumental Variables Approach.” Journal of Political Economy 112(4): 725-53.

Muscat, Robert. 2002. Investing in Peace: How Development Aid Can Prevent or Promote Conflict. New York: M. E. Sharpe.

Ndaruhutse, Susy, and Laura Brannelly. 2006. "The Role of Donors in Creating Aid Volatility and How to Reduce It." Independent Research Undertaken for Save the Children. http:// www.eurodad.org/uploadedFiles/Whats_New/Reports/Euro dad\%20SCUKAidPredictabilityResearchFINALReport.pdf (accessed August 28, 2008).

Nel, Philip, and Marjolein Righarts. 2008. "Natural Disasters and the Risk of Violent Civil Conflict." International Studies Quarterly 52(1): 159-85.

Neumayer, Eric. 2003a. "Do Human Rights Matter in Bilateral Aid Allocation? A Quantitative Analysis of 21 Donor Countries." Social Science Quarterly 84(3): 650-66.

Neumayer, Eric. 2003b. The Pattern of Aid Giving: The Impact of Good Governance on Development Assistance. London: Routledge.

Nielson, Daniel L., Ryan M. Powers, Michael J. Tierney, Michael G. Findley, Darren G. Hawkins, Robert L. Hicks, Bradley C. Parks, J. Timmons Roberts, and Sven E.
Wilson. 2009. "AidData: Tracking Development Finance." Presented at the PLAID Data Vetting Workshop, Washington, DC. http://www.aiddata.org/research/releases (accessed February 15, 2010).

Nielson, Daniel L., and Michael J. Tierney. 2005. "Theory, Data, and Hypothesis Testing: World Bank Environmental Reform Redux.” International Organization 59(3): 785800 .

OECD. 2006. Development Cooperation Report: Efforts and Policies of Members of the Development Assistance Committee. Paris: OECD.

Palmer, Gleen, Scott B. Wohlander, and T. Clifton Morgan. 2002. "Give or Take: Foreign Aid and Foreign Policy Substitutability." Journal of Peace Research 39(1): 5-26.

Powell, Robert. 2004. "The Inefficient Use of Power: Costly Conflict with Complete Information." American Political Science Review 98(2): 231-41.

Powell, Robert. 2006. "War as a Commitment Problem." International Organization 60(1): 169-203.

Raddatz, Claudio. 2007. “Are External Shocks Responsible for the Instability of Output in Low-Income Countries?” Journal of Development Economics 84(1): 155-87.

Reed, William. 2003. "Information, Power, and War." American Political Science Review 97(4): 633-41.

Rodrik, Dani. 1999. "Where Did All the Growth Go? External Shocks, Social Conflict, and Growth Collapses." Journal of Economic Growth 4(4): 385-412.

Rosenbaum, Paul R., and Donald B. Rubin. 1983. "The Central Role of the Propensity Score in Observational Studies for Causal Effects." Biometrika 70(1): 41-55.

Rubin, Donald B. 1986. "What Ifs Have Causal Answers (Comments on 'Statistics and Causal Inference' by Paul W. Holland)." Journal of the American Statistical Association 81(396): 961-62.

Sambanis, Nicholas. 2004. "What Is Civil War? Conceptual and Empirical Complexities of an Operational Definition." Journal of Conflict Resolution 48(6): 814-58.

Sekhon, Jasjeet S. Forthcoming. "Multivariate and Propensity Score Matching Software with Automated Balance Optimization: The Matching Package for R." Journal of Statistical Software.

Slantchev, Branislav L. 2003. "The Principle of Convergence in Wartime Negotiations." American Political Science Review 97(4): 621-32.

Uvin, Peter. 1998. Aiding Violence: The Development Enterprise in Rwanda. West Hartford, CT: Kumarian Press.

Wagner, R. Harrison. 2000. "Bargaining and War." American Journal of Political Science 44(3): 469-84.

Wilson, Sven E., and Daniel M. Butler. 2007. "A Lot More to Do: The Sensitivity of Time-Series Cross-Section Analyses to Simple Alternative Specifications.” Political Analysis 15(2): 101-23. 